\title{
Learning by Interest: Experiences and Commitments in Lives with Dance and Crafts
}

Ann-Marie Laginder and Jorun M Stenöien

\section{Linköping University Post Print}

N.B.: When citing this work, cite the original article.

The original publication is available at www.springerlink.com:

Ann-Marie Laginder and Jorun M Stenöien, Learning by Interest: Experiences and Commitments in Lives with Dance and Crafts, 2011, Vocations and Learning, (4), 2, 151-167. http://dx.doi.org/10.1007/s12186-011-9055-8

Copyright: Springer Verlag (Germany) http://www.springerlink.com/

Postprint available at: Linköping University Electronic Press http://urn.kb.se/resolve?urn=urn:nbn:se:liu:diva-69948 


\title{
Learning by interest: Experiences and commitments in lives with dance and crafts
}

\begin{abstract}
In this article we intend to contribute to the understanding of interest-driven learning which occurs when people find and choose an interest of their own. This engagement continues over a long time and includes development and learning. The empirical material consists of fourteen learning stories written by experienced and skilled informants in folk dance and different crafts. The purpose is to illuminate the diversity and complexity of learning and meaning the informants assign to dance or crafts. This is what we consider to be the perspective of learning by interest. We also argue for the importance of understanding learning by interest as embedded in cultural heritage and social and cultural changes. Theoretically, we draw on John Dewey (1913/2009; 1934/2005). Learning folk dance or crafts is largely a question of learning by doing, which makes experience important. The interest and effort involved can in our interpretation be understood as experiences where expressions of commitment are embedded. The empirical analysis highlights three emphases in this illumination of the learning process. The first considers the individual development of skill in relation to broadened learning of collective tasks. The second perspective focuses on the interplay between learning in a life course and significant learning experiences. The third concerns the interplay between personal meaning and craftsmanship. In sum, this paper contributes to the understanding of learning by interest as a useful concept. In the final discussion we expand our perspective since the contrast is obvious between learning by interest and interpretations of the contemporary society, where individualization and lack of commitment is stressed.
\end{abstract}

Keywords: Learning by interest, Dewey, experience, commitment, learning stories, folk dance, crafts

\section{Learning through interest}

This article elaborates the process of learning through interest. It is based on findings from a study focusing on 'the learning landscape of voluntariness' (Frivillighetens læringslandskap) (Thommessen 2009; Stenøien \& Laginder 2009; Laginder \& Stenøien 2009). This concept is the foundation of popular education in Nordic countries. The landscape of voluntariness is part of old as well as new social movements, which have both acted for change and to preserve social, political and cultural forms (Kjeldstadli 2000). Participation and learning is held to be formed through interplay between the individual and different collective practices and ideas (Stenøien 2003). The concept 'landscape of voluntariness' accounts for the activities in the world of voluntary organizations, study associations and social movements, but also goes beyond these. This large open interest-driven field of voluntary activities is, according to Illeris (2007), a learning space that is important to society. This learning space offers almost limitless possibilities for learning based on strong personal interest and motivation.

Learning folk dance and crafts comprises an important social and cultural development in society that has changed the position and meaning of these activities. For those born before the middle of the 19th century, and who grew up in the countryside or in small villages in Norway and Sweden, a general assumption is that self-sufficiency was often part of life (Buggeland 2000). Skills in handicraft were necessary for everyday life and living. 
These were skills individuals were likely to be 'educated' in as part of growing up. The process of industrialization, mass production with increased access to readymade goods, together with work outside the household have, for most people, changed this pattern (Waldén 1999). Handicraft skills are often no longer necessary for everyday life. Handicraft has become something people choose to learn, rather than an imperative for daily existence. With this change in conditions and meaning, we cannot be sure that the know-how is passed down from generation to generation. To a greater extent, the 'transfer' of knowledge and learning has to be taken care of and acquired in contexts other than the family and the neighbourhood. The learning landscape of voluntariness i.e. cultural organizations, study associations and folk high schools offers courses, study circles and other learning opportunities in crafts as a means for securing that inter-generational transfer. In addition crafts can be learned in formal education on different levels.

In a similar way, the traditional dances as relaxation and solidarity in the local communities seemed to have been an integrated part in life at the beginning of the 19th century. In Liljegren's (2004) studies of comprehensive archives in Sweden, she formed the impression that people danced whenever an opportunity occurred, e.g. celebrations, parties and other social events. Although dancing as such may still be part of a common form of relaxation and local solidarity, the interest in learning folk-dances in contemporary society is one that individuals actively choose. The learning takes place together with other people although not necessarily family members or close friends. It is more likely to take place in courses or other organized opportunities for learning. The tradition of folk dance is to a great extent learned within the same kind of voluntary associations as well as formal educational arenas as traditional crafts. This insight serves as an important background for the interpretation of individuals' long-lasting learning interest through cultural activities. In a previous article, we considered how individual choices to engage continuously in folk dance and crafts interacted with learning over time. The result showed how meaning was assigned to the interest, and how the interest (folk dance and crafts) are embedded in cultural traditions and changes on a social level (Stenøien \& Laginder 2009). It could be said that these changes in the position and meaning of dance and crafts in society have also changed them as experiences. This reflects Hannerz definition of culture as "the meaning which people create, and which creates people, as members of societies" (Hannerz 1992, p. 3). Here, we aim to deepen the understanding of interest-driven learning by means of tentative ways of understanding and conceptualizing learning that occurs when people find and choose an interest of their own that continues over a long time. This means that we at first need to present our methodological tool which provides us with individual stories about interest-based learning that visualize learning and meaning-making as an on-going process in life.

\section{Learning stories}

Researchers in Europe have defined the increasing use of biographical and life history approaches in the field of adult education as the "biographical turn". According to West et al. (2007), this should partly be understood as a reaction against research that marginalises perspectives of subjects themselves or reduces subjective processes such as learning in favour of supporting abstract entities. This is also a reaction against theories where learning is perceived as largely predetermined processes, and where notions of agency and meaning making become unimportant and are rejected (West et al. 2007, p.12). With reference to Weber, they propose that:

The study of life history or biography offers a more nuanced view of how wider forces constantly intervene in individual lives but how responses and actions vary enormously 
from person to person, even in similar 'objective' situations (West et al. 2007, p. 15 (Weber 1998)).

A consequence of the biographical turn is, according to Tedder and Biesta (2007), a much broader conception of learning:

(A concept of learning) which does not restrict the meaning of learning to institutional definitions, but which includes the cognitive and reflexive dimensions of learning as much as the emotional, embodied, pre-reflexive and non-cognitive aspects of everyday learning processes and practises (Tedder \& Biesta 2007, p. 3).

The empirical material in our study is autobiographical in the sense that we invited people to write their own narrative about how they learned what they know in folk dance or crafts. The informants were recruited via cultural organizations and study associations that organize studies in folk dance and crafts. An invitation was distributed which requested people to write down how they learned to be skilled in dance and crafts. Those who accepted the challenge were persons with extensive experience in folk dancing or crafts. It might expect that their engagement in cultural organizations meant that they primarily focused on participation in organized learning in the landscape of voluntariness. However, this was not the case; they literally told stories about learning through their whole life, in a variety of situations and contexts. They talked about childhood, adolescence and adult life with desire and a longing for deepened learning. By following their interests they have chosen to participate in both voluntary informal learning and formal education, but they also formed their own learning opportunities - field of interest.

Fourteen stories were sent to us anonymously in 2006. Seven women and two men wrote about their interest in crafts. Their age varied between 43 years to 73 years. Four women and one man wrote about their learning in folk dance. They were aged between 19 and 46 years. Two informants came from Sweden, and the others were from Norway. The stories resembles life stories, which are narratives written or told by the person herself about her own life (Slettan 1994, West et al. 2007). In our case, however, the concept of learning stories is more suitable because the invitation was to focus on learning experiences. Writing these learning stories gave the author the opportunity to decide how much time he or she wanted to use in writing the story and to formulate and rewrite in his or her own way. The individuals had a few supporting questions to guide them when writing, what we have chosen to call their learning stories. These comprehensive questions focused on how the individual interest began, where and how they learned different kinds of crafts or how to dance, why they continued to learn more and if they are still learning new things. The stories vary in length, from just over one page to up to ten pages. Some of the informants used the questions as their starting point, while others did not.

Our informants were encouraged to write about involvement, learning and activity in connection with a particular field of interest. There was no limitation in time, i.e. when, where or how the interest arose, was learnt or put into practise. It could be learning both as a hobby and work-related. The stories, in this sense, comprise the full life course, both in length and breadth. Learning stories makes it possible for the informants to bring together learning, experiences and insights that have been acquired over time in many different contexts. Depending on the individual's life circumstances and ambition to maintain their involvement as a recreational activity or to become professional, we can see how they movs between voluntary informal learning and formal education and how they form their own learning opportunities. In addition, the stories also provide examples of the ways their involvement is 
situated in a fellowship with like-minded others. Our main interest is to analyze the learners' individual ways of becoming skilled via numerous options for learning.

The stories will, however, always use a repertoire of cultural forms, scripts and ideologies. The contextualization in this article is primarily theoretical. A cultural imperative that is part of the learning stories context is how the cultural meaning of the object of interest (folk dance and crafts) changes over time. Our interpretations of the learning stories highlight bonds with cultural heritage and collective experiences in society, which we have written about in earlier articles (Stenøien \& Laginder 2009; Laginder \& Stenøien 2009; Laginder \& Stenøien 2010). We find that learning stories make it possible to provide some insights into how learning experiences are formed in a lifelong perspective. We can summarise the learning stories by saying that they have the potential to clarify different learning progressions and meanings in a life perspective.

The purpose of the interpretations in the forthcoming analysis is therefore to elaborate the diversity and complexity of learning and the meaning the informants assign to dance or crafts. Expressions of delight and joy in dancing and exercising crafts are a common theme in all stories. In this article, we focus on six of the learning stories; Daniela, David and Disa who told about learning folk dance and Henriette, Henrik and Hjørdis who wrote about learning crafts. These informants have written detailed learning stories. This means that the stories help us to interpret how different learning contexts came into play and how the interest was inserted in a broad learning in culture organizations. The aim is to deepen the understanding of interest-driven learning in the individual's life as regards folk dance and crafts. At first we introduce our theoretical understanding of the concept learning by interest.

\section{Learning by interest: a theoretical framework}

The theorizing of learning by interest is advanced here in three steps. The starting point is our basic statements concerning learning. These perspectives have been used in previous analysis of all learning stories. We present some of our main findings. Then, we focus on the concept of interest. Here we draw on Dewey's interpretations. To make learning by interest useful in the forthcoming empirical analysis we elaborate the concept further in the third step by using the concepts of experience and commitment.

\section{Perspectives on learning}

Our theoretical frame of reference for understanding learning has two different points of departures. The first one refers to the complex nature of learning as interplay between the individual and his/her surroundings, which has attracted the interest of many researchers (e.g. Billett 2006; Stenøien 2003). A theoretical framework that does not view learning as either individual or social is found in Hodkinson et al. (2008). They theorize this dualism, argue for a holistic standpoint and discuss problems interlinked with different interpretations of learning in relation to work in general. For example, learning in the workplace is significantly different from specialist education and training. Their criticism is that the current literature focuses on just one kind of learning and learning context at a time. In addition, to understand learning based on the different learning situations is not enough, the perspective of the individual learner is also needed. The holistic view also include that "we need to understand learning at any one time as part of a lengthy on-going process, where the past life-history of the individual and the past history of the situation strongly influence the current learning" (Hodkinson et al. 2008, p. 28). This means that learning in the past and present is influenced by wider social, economic and political factors. These factors lie both outside and inside the individual and the learning situation. The result is an understanding of learning as an interrelationship between these issues and the lengthy on-going learning processes. 
The second premise is our assumption that the individual learning experiences cannot fully be understood if divided into and studied as single events experienced in separated arenas of organized learning. Dreier (2000) argues along these lines when he focuses on the importance of understanding learning through the individual's participation in several contexts and activities. Daily living and personal participatory trajectory constitute, according to Dreier, a changeable structure, aim and direction in the individual's life (Dreier 2000, p. 94). This trajectory places the focus on the learner's own activity and use of different contexts for action and learning. No explicit instructions are needed. Learning becomes in this sense self-organized. Nevertheless, the setting, situation, actual learning context provide different kinds of guidance in the learning process. Our previous works suggest that the devotion to an interest such as folk dance or crafts varies among individuals. We found that some of them made choices that had consequences for their whole life, while others made choices that were more limited. One of our conclusions was that the choices were shaped and became meaningful in the interplay between the subjective preferences and the surrounding contexts. It was through this tension that the learning processes were enacted (Stenøien \& Laginder 2009, p. 81). In later articles, we developed the interpretations of this process of learning further. One main finding was that the distinction between leisure and professional work became blurred when interest-based learning in a life perspective is the focus of attention. It made us aware of the interplay between, on the one hand, creating something and creating oneself and, on the other, becoming skilled, attaining goals and making something useful for others (Laginder \& Stenøien 2009a; 2009b; 2010). This interplay appeared in the development from a leisure interest into a professional practice. One of the informants describes how her interest in knitting since childhood becomes professional through the use of a knitting machine. Yet, this tool used for production reduced her enjoyment of handicraft. She said that she liked her work but when she was free she wanted to do something else (Laginder \& Stenøien 2009b, p. 122). In other words our results highlights how the boundaries between leisure activities and professional practice merge and change and how new boundaries are shaped over time.

Consequently, here we intend to deepen the understanding of interest-driven learning by focusing on the concept of interest. In the first section, we state our general understanding of the concept. In the next section, we develop the understanding by using the concepts of experience and commitment.

\section{The concept of interest}

Our starting point is John Dewey's interpretation of interest in relation to effort (Dewey 1913/2009). He proposes, a genuine interest stands out as an absolute necessity for individuals to be themselves.

Genuine interest, in short simply means that a person has identified himself with, or has found himself in, a certain course of action (cited as seen Dewey 1913/2009, p. 43).

His interpretation of interest highlights its moving, developing nature and characterizes by a holistic experience. The activity means something and this meaning contributes to the development of the activity. Similarly, he argues that effort is significant only in connection with a course of action. He is talking about an expanding activity and that the "demand for effort is a demand for continuity in the face of difficulties" (Ibid., p. 47). When the action is developing or growing, the energy put into it is demonstrable, according to Dewey: i.e. how much a person really cares for it. What is significant is not simply effort but its connection with advancing the activity forward to securing its completion or resolution. He stresses the connection of the experience of effort with thought. We conclude, therefore, that Dewey's 
interpretation of interest is of crucial importance in conceptualizing interest-based learning in a life course. It contributes a platform for explaining the learning that occurs when people find an interest such as folk dance or crafts, an interest which continues over a long time and includes development and learning.

To make learning by interest useful in our empirical analysis and interpretation, we need to develop the concept of interest further. First, we introduce Dewey's interpretation of an experience after which we will discuss the concept of commitment.

\section{Concepts of experience and commitment}

Learning dance and crafts is very much a question of learning by doing, which emphasizes experience. Observing this learning over time also makes learning processes visible. Having an experience, according to John Dewey (1934/2005), occurs when the experience is fulfilled. He exemplifies with experiences we spontaneously refer to as "real experiences" with tremendous importance but also those which are negligible. According to this, an experience, whether it is of great or little importance, stands out as an enduring memory. When speaking about learning, we can compare this with the concept of significant learning experiences (Antikainen et al. 1996). Referring to Dewey, Antikainen et al. propose that the key factors in learning and human development are the quality and continuity of experiences. And, their significance can consist of definable events or cumulative developments over time. In the learning stories, we find significant learning experiences of both types (Laginder \& Stenøien 2010). According to Dewey, experiences are based on common patterns as a result of interaction between individuals and their surroundings. An experience is gained by doing and undergoing a consideration of what has been experienced. In undergoing there is suffering in a broad sense. This means that an experience of importance needs to be taken in, involving reconstruction, which may be painful. It is the actual circumstances that determine whether the necessary undergoing phase becomes painful or pleasurable.

Struggle and conflict may be themselves enjoyed, although they are painful, when they are experienced as means of developing an experience; members in that they carry it forward, not just because they are there (Dewey 1934/2005, p. 42).

The interest and effort involved in moving the activity forward to its fulfilment can, in our interpretation, be understood as experiences in which expressions of commitment are embedded. Interest-driven learning points to, as we mentioned earlier, both the need for individuals to be interested enough to choose a field of interest and also to find it meaningful enough to develop their involvement and to seek opportunities to learn in a more or less selfdirected way. Nonaka (2004) refers to Polanyi when claiming that commitment underlies human knowledge creating activities. From this point of view, commitment should appear everywhere, as is detailed in individual and organizational studies, commitment does appear. Nonaka (2004) finds that it's generated by intention, autonomy and fluctuation in organizational settings. From a societal perspective, commitment seems to vanish. Social scientists have claimed for decades that many social problems stems from lack of commitment (Beck 1992; Bauman 2007; Giddens 1992; Putnam 2001; Sennet 2006). We will return to this later.

In the late 1960s, Rosabeath M. Kanter (1968) defined commitment by focusing on the interplay or meeting between the individual interests and the prescribed organization's social patterns: 
Commitment may be defined as the process through which individual interests become attached to the carrying out of socially organized patterns of behaviour which are seen as fulfilling those interests, as expressing the nature of the person (Kanter 1968, p. 500).

Continuous commitment was one of three types of commitment which Kanter (1968) found in her study of social commitment in utopian communities. The others were cohesion and control. Commitment when it appears in learning by interest unfolds in a more varied landscape and individuals making their own choices and deciding how the interest is formed. Commitments are embedded in the development of personal engagement formed through an ongoing interplay with its surroundings. This interplay might emerge as expressions of continuity, cohesion and control. The focus on commitment as a process is analogous to Firat et al. (2009) who re-define the concept from commitment as being, to commitment as practice. They focus on the inherent tension in commitment as an intellectual but locally embedded practice. The question to ask is reformulated from "to what or how are you committed" to "how do you do commitment" (Firat et al. 2009, p. 7). Sennet (2009) seems to take "commitment as practice" further or in a slightly different direction in his focus on "craftsmanship", defined as a desire to do something well for its own sake. While Firat refers extensively to intellectual commitment, in craftsmanship Sennet explores dimensions of skill, commitment and judgment. He expands the concept of craftsmanship to include the practice of scientists. In this way, Sennet bridges the difference between the intellectual and the craftsman practice, mind and body. Craftsmanship is not just about doing, it is also about reflecting and judging. Or as Dewey put it in his discussion of art and experience, craftsmanship to be artistic must in the ultimate sense be 'loving' - "it must care deeply for the subject matter upon which skill is exercised" (Dewey 1934/2005, p. 49).

Our focus on interest-based learning as lifelong learning processes in a cultural approach is consistent with an understanding of commitment as process and practice. Commitment becomes dynamic; it expands from being to doing and is not only embedded in the individual learning interest but also integrated in the changing social and cultural forms and expressions. To summarize, the perspective learning by interest is based on Dewey's concepts of interest and effort. We will analyze the learning stories drawing on the above reasoning and interpretations of the concepts of experience and commitment.

\section{Learning by interest in lives with dance and crafts}

Learning stories, written or told from an individual perspective cannot provide a complete picture of interactions between the individual and his/her surroundings. In other words, it is not possible to satisfy all the expectations built into the theoretical frame we draw on. Commitments and experienced practices which reflect contexts is what these learning stories provide us with. The lifelong perspective makes it possible to notice change. Expectations and possibilities of understanding interplay between individuals experiences of learning and meaning, their surroundings and patterns of commitment are also inherent in the framework. In analyzing six of the learning stories, we use the theoretical framework to highlight three perspectives of interplay. The first perspective considers the individual development of skill in dancing or crafts in relation to tasks concerning development of the cultural organization. The second perspective focuses on the interplay between learning in a life course and significant learning experiences. The third perspective concerns the interplay between personal meaning and craftsmanship.

\section{The interplay between personal, common interest and commitment}

Interest-driven learning strengthens per se the personal-interest but our findings shows that the personal-interest is interwoven with common interests in the organization. Dancing is fun 
and instructive. Daniela, born in 1987, thinks of dancing as an opportunity to meet new people and form friendships within and across generations:

Dancing to me means being with people who feel the same joy of dancing, meeting new people and creating social interaction, finding friends - not only people of my age but also friends who are older and younger. The joy of dancing emerges when a difficult dance can be performed without thinking, when the interplay between the dancers functions so well that dancing is like a game.

By participating in the Tuesday dancing and other events she continues to be part of the community formed by Norwegian Youth League, where she started dancing at the age of four. This participation in the same learning space expresses continuity in the social commitment (Kanter 1968). Moreover, the substance of this continuing commitment is the personalinterest in dance expressed and developed through dance practised over a long time (Firat et al. 2009). What characterises Daniela's involvement is, nevertheless, that she loves new challenges, and she has found new challenges in aspects that are not directly related to the dance floor. She eventually attended courses to become a dance instructor and has led courses herself. She has also become involved in new projects staging dance shows. This meant learning things far beyond dancing per se. She has also taken on duties as a member of the organization's board, thus participating in the administrative and organizational activities, writing: "Dance has become more than dancing." This makes it an extension of the original activity, although always relating to the togetherness of dance. Even more important is that these extended activities point to a commitment in practise that goes beyond the personalinterest and constitutes a commitment to the association (Firat et al. 2009). This is expressed in the same space (i.e. voluntary sector), which in other words seems to provide a range of possible learning contexts. To sum up, commitment is expressed in multiple ways in concrete action. In this way, combined commitments evolve in practice over time and through participation.

Henriette, born in 1944, wrote about a continual lifelong interest in arts and crafts and old techniques. Spaces for learning and practicing have been voluntary associations as well as formal education in arts and crafts and, as an adult, always in addition to a full-time job. After moving to a new neighbourhood, she joined the local housewife association where a common interest in creating and sewing a local national costume developed among the association's members. Her crafts interest now turned into a learning process where the focus was on sewing local national costume, and thus also became her field of in-depth interest. This is more like a craftsman commitment described by Sennet: “...seeking to do the work well for its own sake" (Sennet 2009, p. 9). This involved participating in courses to learn how to create national costumes, and also sharing knowledge with others by arranging courses. There was also the sense of togetherness with those interested in sewing national costumes, and together they explored and recreated old techniques and designs. This commitment involved learning, knowledge development and sewing this particular type of national costume. This interest has lasted many years: "Many national costumes have been made over the years, for women, men and children". Her interest in making national costumes has been maintained almost throughout her entire adult life, and has thus come to mean a lasting in-depth interest and specialisation. Henriette's deep interest in sewing was at any rate the starting point and in many ways the driving force for a collective orientation and commitment in the association. Her commitment to crafts work seems to develop through interplay with social forms of commitment such as cohesion and continuity.

In Henriette's narrative we see how her involvement in a broad association space led to deeper interest in national costumes and how to sew them. In Daniela's narrative we saw 
the opposite, how her interest in dance led to a broader involvement, working for the association as an instructor and as a member of the board of the rural youth association. The high value of a long lasting interest in dance and handicraft is clearly documented in both of these narratives. It is also obvious that learning by interest can take different paths/constitute different patterns. The interest can be a core of the individual's learning and doing activities in other learning contexts (than the dance floor) as well as being the main focus of doing, with an involvement in knowledge development, where learning opportunities are chosen to develop skills.

\section{Significant learning experiences in a life course}

Our first example illustrates how the beginning of the informant's interest in learning dancing depended on his surroundings. David's narrative makes it clear that growing up in a small island community was decisive for his starting to take part in folk dancing, or in his words "joining folk dancing was given". He was born in 1978 and is 28 years old, and being together with other young people was an important factor in his decision to continue dancing: "there were other boys who danced, cute girls, folk dance instructors and the trips that were arranged." His narrative illustrates a learning process over time that appears to be close to a tradition of mimicking (Liljegren 2004). He states that the oldest of the young persons and two adults were running the folk dance club for the young and teaching them.

There were talented dancers among the older boys, and they were naturally our idols as dancers and also because they were cool. We had guest instructors too, and particularly those who came to teach us halling (a Norwegian folk dance) were exciting. They danced with their whole bodies, so later you would go home and jump around your living room.

David's reflection stands out as an experience in Dewey's interpretation. We can see that David is taught by the older boy and fulfils the experience of his own learning by doing. Both in his youth and later in his role as instructor he appeared to act playfully and kept close to a mimicking tradition.

I also gained experience as an instructor over time, and as I didn't have any course or formal training in this, my plans occasionally went wrong. But I don't take myself too seriously, and was always honest when I made mistakes, so those I instructed seemed to think this was OK. Perhaps they felt it was not so dangerous for them when even the instructor made mistakes.

Eventually he finds full-time employment in the folk dance movement and claims that he is learning to dance on the dance floor and not through organized courses. He learns a great deal from "watching others in a learning situation, both those who instruct and those who are instructed." In this way he illustrates how his experience is based on participating in practise. David states that dance occupies a major place in his life, having become his principal activity both as his work and as his leisure activity. In this way, the dance trajectory he manages to uphold combines work and leisure. The fulfilment of a complete experience is the driving force of commitment. Referring to Dreier (2000), David creates a personal participatory trajectory, changeable over time but he never loses sight of his aim and direction in life. Our conclusion is that David's learning story highlights the fact that significant learning experiences (Antikainen et al. 1996) occur as definable events, such as his learning in his youth. However, just as important is that his learning over time also reflects significant 
learning experiences as a cumulative development. This shows the complexity in the concept of significant learning experiences.

Disa, born in 1971, exemplifies a different approach and learning story where significant learning experiences occur as clearly definable events. The path of her commitment differs over time. She started dancing when she was young and learned first by joining the children's group and later the youth group in the folk dance association. Here, she found friends, activities and fun. There was "nothing difficult about dancing". Later she joined the adult group. This was not fun and many of the people of her age eventually quit, but she did not. At some point in time it became clear that "now it was too late to quit dancing". This was after she and her father had started to dance in a group dancing the "polska" (a kind of folk dance). This is in line with Dewey's (1934/2005) reasoning about the vital importance of "taking in", which can make elements of suffering necessary for the fulfilment of an experience.

It was a "hard school we came to. Here, it wasn't good enough to do something almost right." This dance group practised towards a goal, which was to be "assessed and approved for a medal by a jury at the annual polsk dancing competition". This represented a transition in Disa's dance commitment that implied a risk.

There was something unspoken and obvious that we should manage this. The risk of being disapproved of was frightening (...) If we had been, the only option would have been to hang up the dancing shoes for good.

This event was, nevertheless, what led her to continue to immerse herself in precisely this type of dance. She chose, in line with the ideas expressed by Kanter (1968), to surrender to the community's rules and risked mortification if she was disapproved of. Still, these parameters for her practice became the mechanisms that made her continue. The reason for this was that there were goals to aim for - it took five years to be eligible for the Big Silver medal - and that was tempting. The second event was when she took courses in dance at a folk high school. This also contributed to maintaining her dance involvement and resulted in a completely different practice, which gave it a new direction. At the folk high school, she encountered a totally different way of thinking and another dancing practice compared with what she knew from before:" Earlier, I had always been told what was right and what was wrong. Here nobody told you how to do it right." For her, this was an entirely new approach and she struggled with it. One of the aspects she found disconcerting was the idea that what each individual knew led to a new dance, a new way of moving. For her, this seemed to conflict with her understanding of "doing something well" according to a predefined collective standard well known from traditional craftsmanship workshops (Sennet 2009). Disa's later reflection was that: "This year really changed my way of seeing and thinking of dance".

This year, thus, led to a change. Her dancing commitment took a new turn and led her to apply for formal dance education so that in the end she became a dance instructor. As we can see, Disa has gone through three entirely different learning progressions, two of which she appears to be ambivalent about. Where one was immersion in something that meant doing things right in relation to predetermined standards, the other challenged her to improvise and trust her own perception, and thus create dance. Her commitment in practise is an expression of surrendering to the rules of the actual context. Disa's learning story reflects Hodkinson et al.'s (2009) understanding that transfer of knowledge does not just happen. 'Learning as becoming' is the notion used to describe how learning happens in one context (or space - see Illeris 2007). This learning experience will, however, appear in another space as modified dispositions which may or may not assist in the new process of becoming through learning, for example, from student to worker. 
Disa's interest in dance has developed into performing professionally and she does not dance much for fun anymore. For her, the important thing is that she likes who she is dancing with.

Naturally I dance as often as I can with my dance friends who are more like colleagues now. This is when I am reminded why I love dancing. (...) This is when we can find new ways, you feel new things. Without anybody saying anything it becomes good, you just know it. Like we have a sixth sense for feeling dance.

Here, Disa also illustrates how commitment can change when it leads to professional development and shifts from a leisure activity to a profession. Her expectations with respect to the perception of dancing have grown. She also expresses "craftsmanship" along all three dimensions of Sennet (2009), i.e. commitment, skills and judgement.

\section{The interplay between meaning and craftsmanship}

Personal meaning in the form of inner perception of practising handicraft is expressed in a number of ways in the learning stories. A prominent feature is the joy of creating with one's own hands. This joy has many manifestations. First, there is the physical experience, the pride in one's own abilities and greater self-confidence. Second, the informants refer to meditation and relaxation benefits, reflecting a spiritual calmness or experience. The concentration expressed in the narrative can involve both the freedom to create something new, becoming a visionary in a way, and the more or less mechanical activity that allows one's thoughts to soar freely.

Henrik, born in 1961, encountered handicrafts as part of his parents' leisure activities:

... neither of my parents were particularly outstanding when it came to the level of the craft, but they enjoyed it. And there was always this good and intimate mood when they were working. A special peace and calmness. Perhaps that's what I'm looking for?

His memories from childhood stand out as a significant experience in his reflection. As an adult, he chose to start studying folk art in higher education. This choice gave his life a new direction. This was a career choice that had consequences for other central choices in life, marriage and work.

I learned a lot during those years, accumulating knowledge together with others through practical work. When a group of people who are interested in the craft are sitting together whittling while contemplating in front of a fireplace for a year or two, everybody develops.

This reflection can be understood as a complete and compelling set of experiences. According to Dewey (1934, reprinted 2005) fulfilment goes beyond waiting for the work to be finished. Throughout the whole process, fulfilment is anticipated and felt very strongly. Henrik illustrates what Antikainen et al. (1996) describe as significant learning experiences that stress the cumulative characteristics rather than a definable learning event that changes the life course. He explicitly interprets the fulfilment of the experiences.

It makes me incredibly happy to create with my own hands. I relax from things that stress me and enter a kind of trance. Whittling, or embroidery for that matter, is meditation, it is joy, it is to create, and it is to see. It is life itself. 
Hjørdis, born in 1965, also expresses a holistic experience in which her own creative powers and knowledge are in focus.

Now it's only your own hand and tools with sharp blades. The silence, the sound of the blade against your workpiece. My own breath, the rustling of leaves and a squirrel watching. ... When the day is done, and there's an object there, created exclusively by means of my own powers and knowledge. Just fabulous, almost a religious experience. Then I learnt much about the essence of arts and crafts. The filter between you and what you are working on must be as small as possible.

For Hjørdis, the field of arts and crafts is a lifestyle. She points out that on the individual level arts and crafts is the most visible "arena for mastering". She has also trained in a craft, but for financial reasons she has not been able to live up to the ideal that a "true craftsperson" is one who practises the craft. Time does not even stretch far enough to satisfy the family's need for objects. She expresses commitment toward craftsmanship and a responsibility for the continuance of this kind of knowledge. Therefore, it follows that Hjørdis believes that handicrafts and handicraft knowledge are of fundamental importance in society, and that it would be quite problematic if the usefulness of handmade products were to disappear. This is quite consistent with what Waldén (1999) claims; that if manual work is to survive as more than something taking place in museums with a few (but skilled) practitioners, if it is to retain its popular roots, it must have a place in our time and satisfy the needs of those living today (Waldén 1999, p. 86).

Learning by interest comprises, and is maintained through, a positive interplay between fulfilled experiences that affect the individual (and/or community) - and in this way may change - and involve meaningful practices. To be or feel affected is a principal aspect that promotes social commitment (Stenøien 2003) and commitment as practice (as we have seen in the learning stories). We might conclude that a successful interplay between learning by interest and meaning is based on commitment practises that involve emotions and fulfilled experiences. In addition, we can refer to Dewey (1934/2005), who states that there is an element of passion in all aesthetic perception.

\section{Learning by interest - a diverse and complex concept}

Individuals who pursue an interest, seek activities in different contexts that can provide them with appropriate experiences. The learning-interests are formed by the interplay between knowledge, meaning, skills and the joy of doing. In our study, the object of interest, folk dance or crafts, was the starting point and governed the subsequent activities. To be able to see the dynamics of learning involved, time was an important factor. To understand these experiences from an individual perspective one need the individual's own description and meaning making. The learning stories uncover learning experiences that are interwoven with the interest and how they manifest themselves in the individuals' lives. Here, we have been particularly interested in commitments and significant learning experiences and how they are formed by the way individuals pursue their interests. They develop a sense of belonging which promote different activities and sorts of experiences and commitments.

The voluntary choice of devoting oneself to dance or crafts and the endeavours to develop the interest is in contrast with the lack of commitment in society that we pointed out earlier. Provocative questions can be raised about contemporary society and theoretical interpretations - questions about learning, meaning making and identity, but also about individualizing tendencies in society and the management and survival of cultural heritage knowledge. Bauman (2007) discusses contemporary society as a "society of consumers" 
where the individual must turn into a commodity to become a subject. One interpretations of tis concept is that consuming life first and foremost is about being on the move where satisfaction is only a momentary experience. In contrast to a cyclical or linear time, he proposes the "pointillist time" which underlines discontinuity or even "pulverized" time (Bauman 2007, p. 32). The result is a life of rapid learning but also rapid forgetting. He also argues that the consumerist culture is characterized by a constant pressure to be someone else. He points out consequences such as changing identity, discarding the past and seeking new beginnings, which are promoted by the culture as a duty disguised as a privilege.

In a similar way, another sociologist, Sennet (2006), uses Bauman's term "liquid modernity" when he argues against the apostles of the new capitalism when they say that their version of the three subjects of work, talent and consumption, adds up to more freedom in modern society. Sennet claims that the new capitalism has cultural influences far beyond its numbers, constituting features that have consequences for the individual possibility to create coherent life stories, engagement and skills. In particular, three demands and expectations in the new working life are held to promote these societal trends. First, there is the capacity to relinquish the past. Second, the demand that new knowledge must be quickly inscribed implies assigning low value to previous experiences. And last, by easily being able to shift tasks and workplace, individuals show that they are able to handle the demands of readjustment and flexibility. This social order discourages crafts skills such as really worthwhile learning and doing something well for its own sake. Mental mobility eschews the possibility of getting deeply involved and ability becomes a focus on operational technique.

Several aspects presented in the learning stories are in contrast to the societal trends discussed above. There is the emphasis on roots and belongingness in a broad sense as well as culture and tradition. There is the importance of commitment and patience as regards becoming skilled in handicraft and dance, which is highlighted in the learning stories. They illustrate what Dewey calls an experience. We find it interesting that Dewey in his contemporary time states what the threats are:

The enemies of the estethic are neither the practical nor the intellectual. They are the humdrum; slackness of loose ends; submission to convention in practise and intellectual procedure. Rigid abstinence, coerced submission, tightness on one side and dissipation, incoherence and aimless indulgence on the other, are deviations in opposite directions from the unity of an experience (Dewey 1934/2005, p. 42).

There is obviously a clear contrast between the knowledge presented in the learning stories and expectations that result in individuals and consumers constantly being on the move in shifting directions as Bauman and Sennet pointed out. In learning by interest, the search for meaning is combined with the intention of being skilled in the chosen interest. In a life course, this development takes time and is based on both collective and individual experiences. This is in contrast to, and questions, contemporary expectations of rapid learning and swift forgetting. The insights learning by interest gives us could be of help in constructing learning opportunities which aim to promote integration of knowledge, meaning, skills and joy.

We conclude that commitments and experiences are intertwined phenomena. Through the fulfilment of experiences, interests develop and change and can uphold and strengthen commitments. In sum, our tentative investigation of interest-driven learning has identified the understanding of learning by interest as a concept that is helpful in explaining this process of learning. Our aim with this concept and learning stories as a methodological tool is to contribute to theory and practice in the field. The focus on folk dance and crafts provided us with an interesting context for the learning spaces involved. But we argue for the potential use in a more general sense. Learning by interest might, for example, raise some interesting 
questions concerning voluntary and self-defined learning in areas other than dance and crafts. This also applies to education and societies increasing mandatory education.

\section{References}

Antikainen, A., Houtsonen, J., Kauppila, J. \& Huotelin, H. (1996). Living in a Learning Society. London: Falmer Press.

Bauman, Z. (2007). Consuming Life. Cambridge: Polity Press.

Beck, U. (1992). Risk Society. Towards a New Modernity. Longdon: Sage Publications.

Billett, S. (2006). Relational Interdependence Between Social and Individual Agency in Work and Working Life. Mind Culture and Activity, 13(1), 53-69.

Buggeland, T. (2000). Maihaugens bok om handverk. Lillehammer: Maihaugen. De Sandvigske Samlinger.

Dewey, J. (1934/reprinted 2005). Art as Experience. New York: A Perigee Book.

Dewey, J. (1913/reprinted 2009). Interest and Effort in Education. Southern Illinois University Press.

Dreier, O. (2000). Lärande som förändring av personligt deltagande i sociala kontexter. I K. Nielsen \& S. Kvale (red.), Mästarlära. Lärande som social praxis. Lund: Studentlitteratur.

Firat, B. Ö., De Mul, S. \& Van Wickelen, S. (Eds.) (2009). Commitment and Complicity. Palgrave Macmillan.

Giddens, A. (1992). The Concequences of Modernity. Cambridge: Polity Press.

Hannerz, U. (1992). Cultural Complexity. Studies in the Social Organization of Meaning. New York: Columbia University Press.

Hodkinson, P., Biesta, G. \& James, D. (2008). Understanding Learning Culturally: Overcoming the Dualism Between Social and Individual Views of learning. Vocations and Learning, 1(1), 27-47.

Illeris, K. (2007). How We Learn. Learning and non-learning in school and beyond. London and New York: Routledge

Kanter, R. M. (1968). Commitment and Social Organization: A study of Commitment Mechanisms in Utopian Communities. American Sociological Review, 33(4), 499-517.

Kjeldstadli, K. (2000). Arbeiderbevegelsen og andre folkelige bevegelser. I Arbeiderhistorie. Årbok for Arbeiderbevegelsens Arkiv og Bibliotek.

Laginder A.-M. \& Stenøien J. M. (2009a). Learning landscape of voluntariness - choices in lives with dance, arts and crafts. Presented at the ESREA conference: Civil Society as an Arena of Learning - Stockholm, Sweden, June 11.-13., 2009.

Laginder, A.-M. \& Stenøien, J. M. (2009b). Lärande av intresse. Om liv med hemslöjd, hantverk och folkdans. I A.-K. Högman \& M. Stolare (red), I lärandets gränsland. Formella, icke-formella och informella studier igår och idag, (pp. 107-129). Hedemora: Gidlunds förlag. 
Laginder, A.-M. \& Stenøien, J. M. (2010). Lärande av intresse. Om hemslöjd, hantverk och folkdans. I Arsbok om folkbildning 2009, (pp. 69-89) Stockholm: Föreningen för folkbildningsforskning.

Liljegren, M. (2004). Härmtradition och danslärartradition. I E. Grönlund \& A. Wigert (red.) Röster om danspedagogik. Stockholm: Carlsson Bokförlag.

Nonaka, I. (2004). A dynamic theory of organizational knowledge creation. In K. Starkey, S. Tempest \& A. McKinlay. How Organizations learn. Managing the search for knowledge. (pp. 165 - 201).Thompson.

Putnam, R. D. (2000). Bowling Alone. The collapse and revival of American community. New York: Simon \& Schuster.

Sennet, R. (2006). The Culture of the New Capitalism. New Haven \& London: Yale University Press.

Sennet, R. (2009). The Craftsman. London: Peguin Books.

Slettan, D. (1994). Minner og kulturhistorie. Teoretiske perspektiver. Trondheim: Historisk institutt, Universitetet i Trondheim.

Stenøien, J. M. (2003). Den aktive medborger. Nye sosiale bevegelser som møteplasser for kunnskap og demokrati. Trondheim: Vox / Dr.polit. avh. SVT-fak. NTNU Trondheim.

Stenøien, J. M. \& Laginder, A.-M. (2009). I spenningsfeltet mellom individ og kultur. I T. Thommessen (red). Liv og laere. Om loering i liv med dans, husflid og bygningsvern. (pp. 65-84). Trondheim: Tapir forlag.

Tedder, M. \& Biesta, G. (2007). Learning from life and learning for life. Exploring the opportunities for biographical learning in the lives of adults. Working paper 7. Learning Lives. Learning, Identity and Agency in the Life Course: www.learninglives.org

Thommessen, T. (red) (2009). Liv og lare. Om laering i liv med dans, husflid og bygningsvern. Trondheim: Tapir forlag.

Waldén, L. (1999). Handarbetet - hatat och hyllat. I G. Lundahl (red.). Den vackra nyttan. Om hemslöjden i Sverige. Södertälje: Gidlunds förlag i samarbete med Riksbankens Jubileumsfond.

West, L., Alheit, P., Siig Andersen, A. \& Merrill, B. (Eds.) (2007). Using Biographical and Life History Approaches in the Study of Adult and Lifelong Learning: European Perspectives. Frankfurt am Main: Peter Lang. 